\title{
STRATEGIES TO TEACH AN HYPERACTIVE PUPIL IN THE PHYSICAL EDUCATION CLASSES: A STUDY WITH A PRE-SERVICE TEACHER
}

Fábio Castro, Paula Batista, Susana Soares

University of Porto, Porto, Portugal

E-mail: fabio.leandro.castro@gmail.com, pbatista@fade.up.pt, susana@fade.up.pt

\begin{abstract}
Some disorders may affect the teaching process in physical education classes. In the present work an action-research study was conducted in order to know how two work with a single case of a hyperactive pupil in physical education classes. Based in literature, some work strategies were defined and used by a pre-service physical education teacher. Strategies were the adoption of evaluative positive and individual feedback, which had positive results in the self-observation and in the compromise with the exercises; a calm voice, that resulted positive for pupil individually, but not when in interaction with class; an increased responsibility for tasks, that did not work as expected, because the general behaviour of the class was not good too; pupil showed more commitment with the competition, when compared with cooperation tasks; the valorisation of the work in pairs was more positive than the work in group; attribution of gradual autonomy showed that more time and more specific skills of teaching are needed beyond one school year. In conclusion, it seems to be necessary to adapt specific strategies for Physical education, once the most were in the context of other disciplines taught in a classroom context that is very different from gym.
\end{abstract}

Key words: hyperactivity, physical education, strategies.

\section{Introduction}

The hyperactivity has being studied in different areas of interest. The term became a modern word used by different areas, like psychology, and medicine to describe some children's behaviours.

In society hyperactivity appears to be more present, particularly in educational context (Lopes, 2004). The absence of consensus about what hyperactivity is still persisting. Archer (1989) pointed that behaviors heterogeneity and diffuseness characterize this dysfunction and validate that absence of consensus. Nevertheless, some common traces characterize the children with this kind of disorder, and allow understanding some of their attitudes and behaviors.

Lopes (2004) pointed agitation, disorganization, poor social relation, problems of learning, irresponsibility, and laziness as the more evident hyperactivity characteristics. Additionally to the importance of understand what really is hyperactivity is also necessary to understand how to deal with it, mainly in educational context. The same author pointed that pupils with hyperactivity have a deficit of attention, impulsivity and restlessness, what usually is interpreted as a lower intellectual level. Lopes (2004) also stated that language development, discourse structure and immaturity in self-control characterize these pupils. The self-control also disturbs the memory process. For instance, the hyperactive pupil can't remember past 
PROBLEMS

OF EDUCATION

IN THE $21^{\text {st }}$ CENTURY

Volume 42, 2012

20

actions to avoid them in the future. The aspects related with time notion, as such being in schedule, and respect timetables, seem to not be easily accomplished by the hyperactive pupil. These set of characteristics result in an evident social difficulty of the hyperactive pupil in relationships with other people.

At school, according to Sosin (2006, p. 15), the hyperactive pupil could be a "blessing and a disgrace to the teacher" and could "disturb his better plans". There are some studies about hyperactive children in school (Archer, 1989; Barkley, 2002; Chaves, 1999; Cruz, 2008; García, 2001; Lopes, 2004; Parker, 2005; Sauvé, 2006; Sosin, 2006). The issues refers to causes (Archer, 1989; Barkley, 2002; Chaves, 1999; Cruz, 2008; García, 2001; Lopes, 2004; Parker, 2005; Sauvé, 2006), symptoms (Archer, 1989; Barkley, 2002; Chaves, 1999; Cruz, 2008; García, 2001; Lopes, 2004; Parker, 2005; Sauvé, 2006; Sosin, 2006), diagnostics (Archer, 1989; Barkley, 2002; Chaves, 1999; Cruz, 2008; García, 2001; Lopes, 2004; Parker, 2005), treatments to help the hyperactive children's (Archer, 1989; Barkley, 2002; Chaves, 1999; Cruz, 2008; García, 2001; Lopes, 2004; Parker, 2005; Sauvé, 2006). Studies point general approaches to help teachers and parents working with hyperactive children in the classroom context and at home too (Barkley, 2002; Chaves, 1999; Cruz, 2008; Lopes, 2004; Parker, 2005; Sosin, 2006). However, researches about class effective real strategies are missing. They would be fundamental to improve the scholar success of the hyperactive children, namely contributing for successful lessons and for a better integration in classes. The existent references reports educational adaptations in kindergarten (Barkley, 2002; Parker, 2005; Sauvé, 2006), first contacts with school (Barkley, 2002; Parker, 2005; Sauvé, 2006), classroom scenarios (Barkley, 2002; Chaves, 1999; Cruz, 2008; Lopes, 2004; Parker, 2005; Sauvé, 2006). Those references are most of all varied and global.

In Physical Education (PE) educational context Giacomini \& Giacomini (2006) report some studies related to behavior control, multisensory and multifaceted approaches. The studies about behavior control do not specify which strategies are better. The multisensory studies are related to the use of the visual, auditory, tactile and kinesthetic senses, combining the teaching method with the preferences of learning of the hyperactive pupil. Nevertheless does not specify strategies. The multifaceted approaches gave examples of approaches to deal with these pupils in the PE class. The pointed strategies are general: use of tranquility exercises; work in calm environments; use verbal information; explaining exercises objectives; and use of cooperative games instead competition.

Mendes \& Ribeiro (2006) reported the opinion of some PE teachers experienced in teaching classes that include hyperactive pupils. Those teachers concluded that schools are not prepared to deal with this disorder and there is an evident lack of information about it.

Santos (2007), specially referring to Federal University of Rio de Janeiro, state that the undergraduate programs does not include contents that prepare the future PE teachers to teach hyperactive pupils. This seems to be a worldwide reality.

Taking in account the lack of preparation of schools to deal with hyperactive pupils and the lack of specific knowledge obtained by the PE teachers during undergraduate programs, the pre-service teacher (PT) who found hyperactive pupil in a class faced a big and scary challenge.

The purpose of this study was to analyze the effects of the use of some specific strategies to teach a hyperactive pupil, within a PE class, by a PT. 
Fábio CASTRO, Paula BATISTA, Susana SOARES. Strategies to Teach an Hyperactive Pupil in the Physical Education Classes: a Study with a Pre-Service Teacher

\section{Methodology of Research}

\section{The Case Study}

A PE PT of the Faculty of Sport, University of Port, conducted an approach to action research case study at the academic year 2010/2011. The practicum takes place at a middle school in the grand Porto area. The PT was any experience in real context teaching.

The hyperactive child under study (PETER) was a male pupil with thirteen years old inserted in a seventh year PE class of a Portuguese middle school. The PE class were two times a week, one lasting ninety minutes and the other forty-five minutes. Both classes were in the morning period.

The hyperactive child was signed by a medical certificate. The child was being accompanied by a psychologist and was taking drugs for treatment. All the teachers of the child were informed about this diagnostic at the beginning of the school year.

\section{Data Collection and Data Analysis}

The corpus of this study is the PT board diary made in the practicum academic year 2010/2011, from $16^{\text {th }}$ September 2010 to $8^{\text {th }}$ June 2011 . The board diary was used to register the experiences in classes and other situations that include the pupil with hyperactivity.

All the process was based in the reflexive method. The reflection-in-action, and the reflection-on-action were used (Schön, 1987, 1992). At the end of each lesson, the PT (the author) reflected about the effective problems felt in the teaching process. The reflection was registered in the board diary in order to prepare the next session. The board diary was submitted to a content analysis taking into account the following aspects: (i) Focus of the reflection; (ii) the pupil with hyperactivity; (iii) strategies and (iv) results of the used strategies.

The selection of the strategies was based in literature, characteristics of the class, and characteristics of the PE classes. The inexperience of the PT was taking in account too.

\section{Results of Research}

\section{Focus of the Reflection}

The results of the present work are related to two distinct moments in the content reflexion of the academic year.

In the first moment the reflection was related to the class teaching impact and new experiences (during the first semester), focusing in factors such as organizational problems, like transition between exercises and time management.

"... the instruction time should be shorter, as well as the organization of the pupils and the tasks management. The goal is to not repeat information in different groups, maximizing the time in practice, improving the motor density" $\left(1^{\text {st }}\right.$ semester, $10^{\text {th }}$ lesson $)$.

At the initial practicum phase the PT didn't plan any specific strategies to deal with the hyperactive pupil. But, the PT could understand that he had great challenge to face in order to successfully teach. He observed that the hyperactive pupil acted in a distinct way in relation with classmates, especially in the behaviour subject. At this point, the teacher understood that was important to deal with the hyperactive pupil in specific way.

In the second moment (second semester) the reflection focus was the implementation of the strategies and its impact. 
PROBLEMS

OF EDUCATION

IN THE $21^{\text {st }}$ CENTURY

Volume 42,2012

"At the end of the lesson, I spoke once more with him and I made questions about the reasons that made him having that attitudes and behaviours. He answers that he don't like when the people talked loudly and criticise his behaviour..." ( $2^{\text {nd }}$ semester, $12^{\text {th }}$ lesson).

The concern about the hyperactive pupil was present during all the practicum year, but mixed with other aspects related to the class context.

"In this lesson Peter led the warm-up (strategy used to improve the autonomy and the responsibility in tasks), but he joke ..." ( $2^{\text {nd }}$ semester, $3^{\text {rd }}$ lesson $)$.

\section{The Pupil with Hyperactivity}

The recognition of the real problem of the pupil was in teaching practice. In the initial moments the reflections was more related with behaviour problems as it is visible in the next statements

“...the Peter behaviour affects my attention, namely for being constantly in inappropriate behaviours and not cooperating with me neither with the classmates..." ( $\left({ }^{\text {st }}\right.$ semester, $16^{\text {th }}$ lesson);

"...due to Peter behaviour the class control is different and the lessons have been affecting for it. In this lesson, Peter was called to attention and other pupils too" $\left(1^{\text {st }}\right.$ semester, $28^{\text {th }}$ lesson $)$.

After the implementation of the strategies, the reflections express more concern about the hyperactive pupil and the PT tried to understand the efficacy of those strategies.

"After my study about hyperactivity in sport context, I better understand that is necessary to act in a specific way with Peter, as well with the other pupils that have unexpected behaviours." ( $2^{\text {nd }}$ semester, $1^{\text {st }}$ lesson);

"In relation to the detected problems in the last lesson, Peter seems to be better and the strategies that are being used seem to be working..." $\left(2^{\text {nd }}\right.$ semester, $4^{\text {th }}$ lesson $)$.

Another aspect that emerged was the effectiveness of the implemented strategies, reported as specific results:

“...the lesson was positive, with the pupils committed, motivated, and cooperative with me and between them..." ( $2^{\text {nd }}$ semester, $16^{\text {th }}$ lesson $)$;

"Since that lesson, the pupils performance has been different (...). At this class I talk with Peter in order to motivate him to collaborate with me. This factor was very important once Peter has a high influence within classmates (...), this factor may have been crucial for this lesson. The class was totally different from the lessons before." ( $2^{\text {nd }}$ semester, $18^{\text {th }}$ lesson $)$.

\section{Strategies}

\section{Adoption of evaluative positive and individual feedback}

It was observed that the pupil with hyperactivity becomes more involved in classes, namely using the questioning about his performance and exercise more.

"Peter was more concerned with his own performance (...) He questioned about his result, if it was good or not $\left(2^{\text {nd }}\right.$ semester, $13^{\text {th }}$ lesson $)$; 
Fábio CASTRO, Paula BATISTA, Susana SOARES. Strategies to Teach an Hyperactive Pupil in the Physical Education Classes: a Study with a Pre-Service Teacher

"The interrogative feedback in an individual and positive way seems to promote more motivation and commitment in Peter and in the other pupils" $\left(2^{\text {nd }}\right.$ semester, $21^{\text {st }}$ lesson $)$.

$\mid$\begin{tabular}{l} 
PROBLEMS \\
OF EDUCATION \\
IN THE 21 $1^{\text {st }}$ CENTURY \\
Volume 42, 2012 \\
\hline 23
\end{tabular}

Voice

The hyperactive pupil reacted in a positive way when the voice was calm. When it wasn't he react inappropriately, especially when he was called to attention in front of the classmates.

"I want to help you to have success in the exercises, in order that you have the classification that you want (...). After I explained to him and he understood that he has made wrong. Peter said that he will improve his behaviour in the next lessons" $\left(2^{\text {nd }}\right.$ semester, $12^{\text {th }} l$ esson $)$;

“...especially after the dialogue with Peter, I observed his behaviour looking for the strategy efficacy. I could observe that Peter changes his behaviour; he has done everything that I asked, without been inappropriate $\left(2^{\text {nd }}\right.$ semester, $13^{\text {th }}$ lesson $)$.

\section{Increased the responsibility for tasks}

Depending of the context, the pupil revealed more or less responsibility in tasks. The class was one off the factors that influence this positive result with the hyperactive pupil, once it could influence is behaviour"

"...the pupils collaborated in the distribution and management of the materials (...) I had to make an attention call because Peter didn't do what I asked him to do (...) I said: Peter, stop to play with the ball and bring it to me. Do not play with it! ( $2^{\text {nd }}$ semester, $7^{\text {th }}$ lesson);

"...when Peter conducted the warm-up, he tended to joke, affecting and influencing the classmates, especially those that usually have inappropriate behaviours during lessons..." $\left(2^{\text {nd }}\right.$ semester, $3^{\text {rd }}$ lesson).

\section{Competition versus cooperation}

The pupil showed more commitment, motivation and a high level of involvement within motor tasks in competition games.

“... the competition using tournament game improved the pupils commitment (...). During the class Peter asked me when the game began and showed desire to play (...). Peter wanted compulsively play." ( $2^{\text {nd }}$ semester, $22^{\text {th }}$ lesson).

\section{Valorisation of the work in pairs or in group}

The work in pairs resulted more positive. However, it worked better when the pupil could choose his own partner.

“...Peter refers: I don't want to make this with her (...). Peter's behaviour improved when I allowed him to make the exercise with Adam..." ( $3^{\text {rd }}$ semester, $9^{\text {th }}$ lesson);

"...some pupils when does not exercise with the colleagues that they prefer demotivate and the commit with the task decreases (...). When this happens I had to interfere in order to stop the inappropriate behaviours..." ( $2^{\text {nd }}$ semester, $21^{\text {st }}$ lesson $)$. 
PROBLEMS

OF EDUCATION

IN THE $21^{\text {st }}$ CENTURY

Volume 42, 2012

Attribution of gradual autonomy

It is difficult to promote autonomy during the lesson, especially when the general behaviour of the class it is not the best. In fact, it is necessary that the pupil recognizes his own actions.

“...when I try to give Peter more autonomy two different situations happened: or he tend to have unexpected behaviours or some classmates interfere and disturb his involvement in the motor tasks..." ( $2^{\text {nd }}$ semester, $3^{\text {rd }}$ lesson $)$;

"sometimes I feel that I can't do/plan the best strategies to promote the class autonomy, especially Peter's one." ( $2^{\text {nd }}$ semester, $4^{\text {th }}$ lesson $)$.

Results of the strategies used

The pre-defined categories (strategies used) were implemented during all the second semester of the practicum year. The results obtained can be observed in Table 1.

Table 1. Implemented strategies and results.

\begin{tabular}{|l|l|}
\hline \multicolumn{1}{|c|}{ Strategy } & \multicolumn{1}{c|}{ Results } \\
\hline $\begin{array}{l}\text { Adoption of evaluative positive and } \\
\text { individual feedback }\end{array}$ & $\begin{array}{l}\text { Promoted the capacity of self-observation and compromised the hyperactive } \\
\text { pupil with the class tasks. }\end{array}$ \\
\hline Voice & $\begin{array}{l}\text { Individually, the hyperactive pupil calmed when a calm voice was used and the } \\
\text { results were positives. Within the class, strategy does not work so well. }\end{array}$ \\
\hline $\begin{array}{l}\text { Increased the responsibility in } \\
\text { tasks }\end{array}$ & The increase of responsibility was better attained in non-individual tasks. \\
\hline Competition versus cooperation & $\begin{array}{l}\text { The hyperactive pupil was more committed with competitive exercises, namely } \\
\text { games. }\end{array}$ \\
\hline $\begin{array}{l}\text { Valorisation of the work in pairs or } \\
\text { in group }\end{array}$ & $\begin{array}{l}\text { The work in pairs had positive benefits, when the hyperactive pupil could } \\
\text { choose his exercise partner. }\end{array}$ \\
\hline Attribution of gradual autonomy & $\begin{array}{l}\text { The state of autonomy was not achieved by the hyperactive pupil. Possibly, } \\
\text { more time and more teaching experience is needed to observe permanent } \\
\text { changes. }\end{array}$ \\
\hline
\end{tabular}

Strategies used showed, mainly, positive effects, but due to PE specificity, some particular considerations must be done. Namely, the time of intervention must be considered.

Another evidence that emerge was the importance of the class to the integration process of the hyperactive pupil, throw the work in pairs, and tasks with competition elements.

\section{Discussion}

The larger part of the literature about hyperactivity in school puts the thematic in the classroom context (Barkley, 2002; Chaves, 1999; Cruz, 2008; Lopes, 2004; Parker, 2005; Sauvé, 2006). Parker (2005) namely revealed that the problems of the hyperactivity at the school could be more or less critical depending of the instructional style and teacher attitude (Parker, 2005). Those studies point some strategies to deal with hyperactivity considering classes as native language, mathematics, geography and others, but exclude PE. But in some studies, PE is even considered as "a non-structured activity" (Parker, 2005, p. 57). Taking in regard these aspects, 
and considering the very particular condition of the PE classroom, the lack of specific strategies for dealing with hyperactivity is very clear.

One of the strategies to help the hyperactive pupils to have success in the school is teaching him to self-monitoring learning process. This consists in make them observe his own behaviour and evaluate his own performance which expectedly results in a better self-control. The self-monitoring method consists in a written register made by the pupils. Additionally, is clear in literature that the majority of those processes are prepared for pupils of the first school years (Parker, 2005). Taking in consideration PE facilities, the exemplified method is difficult to apply and must be adapt, especially because it is effective in improving behaviour in the task, and interactions between the hyperactive pupils and classmates (Chaves, 1999).

Teaching through the computer is another strategy to successfully teach hyperactive pupils (Cruz, 2008) that does not has direct application in PE classes. In fact, computer is not a typical instrument in PE.

Based on several examples as the ones above, it is important reinforce that in the present study strategies were defined based on literature, but adapt to the PE specific context. The adaptations were made based in the experience of the teacher (PS teacher), and, naturally, in the characteristics of the class too.

The evaluative positive and individual feedback chosen were based on the recognition that simple, specific and brief instructions, repeated once in a time, have more chances to be followed (Parker, 2005). As Parker (2005) state positive feedback allows to capture more attention to the hyperactive pupils and induce him to better act. This does not mean that the pupils are never penalized by its behaviours, like other classmates, but that priority is talk with them, trying that they recognize their on faults. The penalizations, if needed, had always the intention of reorient the pupils to the tasks and make them responsible for his own actions (Lopes, 2004). It is recognized that the punishments that involve the loss of some privileges also have some benefits (Chaves, 1999). Meanwhile, if possible, rewards and incentives should be used instead of punishments in order that hyperactive pupils do not consider that in the school they are more punished than rewarded (Barkley, 2002). The reinforcements should be individualized taking in consideration the preferences and skills of the hyperactive pupils (García, 2001), because it can offset conflicts. From another point of view, the teacher must preserve the contact and maintain an affective relation with the hyperactive pupils to avoid some unexpected behaviours (Sauvé, 2006). At the end of the PS teacher practicum, the option for positive and individual feedback, even that the teacher knew that he had to vary the feedback, namely using descriptive and prescriptive types, had positive effects on the studied hyperactive pupil behaviour. Through direct questions placed to the hyperactive pupil, and most of the times in a positive way, he showed an evolution in motivation, knowledge about the PE contents and commitment with the teacher.

The voice control was chosen for being straight related with the previous strategy. The sound of the voice was controlled in order to transmit peacefulness to the hyperactive pupil in accordance to the positive reinforcements, that should constitute the fundamental core of a program that intend redirect some behaviours (Lopes, 2004). Additionally, when the teacher has to apply penalization to the hyperactive pupils he should avoid exhibit irritation or other emotion who can potentially result in additional negative behaviours (Parker, 2005). Those should instead be applied immediately after the inadequate behaviour, with calm and tranquillity (Chaves, 1999). The praises and other forms of attention, like a smile or a signal with the head, are basic skills that a teacher has to train and use. The hyperactive pupils like to be appreciate, but the attention isolated is rarely enough to solve all the problems (Barkley, 2002). In the present study the PS teacher used a calm voice with the intention to make hyperactive pupil felt calm. The strategy was always a calm talk with the hyperactive pupil, which effect was a raise the confidence of the pupil in the teacher too. The use of that strategy pointed to different results. 
PROBLEMS

OF EDUCATION

IN THE $21^{\text {st }}$ CENTURY

Volume 42, 2012

26

On one side, in an individual way, the hyperactive pupil remained calm and the results were positives, but not so positives in relation with the full class. When strategy was used in all class, the hyperactive pupil felt like if he was special and his behaviour tended to disruption. The pupil tried, in those cases, to show to the classmates that he is over the teacher in leadership. To turn over this situation during the practicum year, the teacher tried to focus the use of that strategy just in an individualized way, abandoning its use in group context.

The strategy competition versus cooperation, curiously, in spite of being directly related with PE discipline is contextualized with the classroom too (Barkley, 2002; Parker, 2005; Sauvé, 2006; Sosin, 2006). The exceptions pointed that PE teachers should minimize collective games with competition and choose activities as gymnastics to promote cooperative learning (Napole, 2008). This is mainly because it's recognizable that the competition appeals for the impulsivity of the hyperactive pupils. The present results pointed that for the hyperactive pupil under study it was exactly the competition that allowed for the good commitment of him with the tasks. High levels of physical activity, cooperation, respect for the rules and responsibility within the team and in game were clearly observable. In fact, he could even dislike a bit of the discipline, but the velocity of exercitation while in game context and the factor win or lose seemed to be determinant for is preference.

The literature is a little scarce about the use of different work types, as pair or group work. However, based in Sosin (2006), we can accept that the teacher must recognise that the pupils have different preferences. Some pupils work better individually, and others in group. Taking the PE class context, the work group seems almost a priority, which leaded to the necessity to adapt exercises management in order to include the pairs work strategy. The PS teacher tried to firstly evolve the hyperactive pupil with healthy behaviour pupils (Sauvé, 2006), trying to get a positive effect from a "good model" (Parker, 2005, p. 57) and then allowed them to be next to a friend previously "encouraged to ignore the [hyperactive pupil] disruptive behaviour" (Barkley, 2002). The work in pairs revealed to have positive benefits, mainly when the hyperactive pupil could choose his partner for the exercises. This showed that, in his particular case, friendship (just with friends that had good behaviour) is important and influences his own interest for the lesson, as well as the success in the exercises. That result could not be observed in group work, even when group was composed just by good behaviour friends of the same and/or different genre. In practice, when the studied hyperactive pupil felt that no one was taking particular attention to him, changed his behaviour and create a disruptive situation that allowed him to pick up the attention of the entire class to him.

The two other strategies applied and related with each other were the increasing of responsibility in tasks and the attribution of gradual autonomy. In what means the first one, literature points that it's necessary to progress step by step and have sure that the hyperactive pupils fully understood the instructions (Chaves, 1999). When the tasks are complex should be separated in small unites and implemented gradually (Chaves, 1999). To pass for complex tasks it's necessary that the be autonomous in simple tasks (Chaves, 1999). Is important for the hyperactive pupil that he wins "dexterity, control, safety and competence" (Sauvé, 2006, p. 73) and this can be done giving him some autonomy, some possibilities of have obligations and make choices. The hyperactive pupils must have new opportunities in proportion with his own management capacities (Sauvé, 2006). In the present study, the hyperactive pupil revealed some acquisitions in autonomy. At the end of the PS practicum year he already could prepare some materials to the class, prepare the context of the exercises (put the materials in the space, for example), give that material to the classmates, and lead some exercises after teacher's explanation. The appearance of positive effects in the sequence of those two last described strategies was constraint by the poor general behaviour of the class. Besides the examples above, the main conclusion is that those strategies did not produce the expected results. This possibly happens because the hyperactive pupil did not achieve the full autonomy. When the pupil was 
taken without supervision, he tended to joke and to create a disruptive situation. It was not possible to understand if that was related with the hyperactivity characteristics of the pupil, or with social education problems, or with the own group turbulent characteristics, or even with an interrelation of all of those factors. Focusing a little bit more in the gradual autonomy strategy, the PS teacher understood that it is probably necessary to work more time with the hyperactive pupil and with the class, in order to test more specific teaching skills and to see changes in the pupil. It is known that the autonomy concept is very complex and global too, which means that it is dependent of the degree of the hyperactivity of the pupil, of the characteristics of the class where the hyperactive pupil was involved, dependent of the beginning of the intervention, of the experience, of the teacher experience, and of others factors (Chaves, 1999; Sauvé, 2006).

Crossing to literature, strategies had changed all over the time, at the same time that the hyperactivity disorder concept and classification changed too (Lopes, 2004). If that so, it is very important to have more contextualized studies, moving from central and general problems to questions like "how to do in PE context", for instance. Concepts and general approaches are fundamental at the beginning, but after some stability it is important to study questions like "how to deal with it in the different scenarios", "how to integrate it", "how to smooth it" "what are the best strategies for the different contexts", "what are the best interactions", "who should talk and deal with it" and others.

\section{Conclusions}

The main conclusions taken from the present study were: (1) The individual feedback with simple questions used positively together with a calm voice revealed positive results and increase the commitment of the hyperactive pupil with the PE discipline, the classmates and the PE teacher; (2) Contrary to some literature results, the competition was more beneficial than the cooperative work for the studied hyperactive pupil. (3) The pairs work (specially with friends with good behaviour) showed more positive results than the group work (without consider the game); (4) The autonomy and the responsibility in tasks seem to need more time to be acquired by the hyperactive pupil.

The challenge of teaching pupils with behaviours problems, namely hyperactive pupils, implies a great investment in the educational process to teach and in the teacher's on-going process.

\section{References}

Archer, S. (1989). Attention Deficit Disorder: clinical and basic research. New Jersey: Lawrence Erlbaum Associates.

Barkley, R. A. (2002). Transtorno de Déficit de Atenção/Hiperatividade (TDAH): guia completo para pais, professores e profissionais da saúde. Porto Alegre: Artmed.

Chaves, E. (1999). Hiperactividade e dificuldades de aprendizagem : análise e técnicas de recuperação. UTAD, Vila Real.

Cruz, E. B. C. (2008). Procedimentos de avaliação e intervenção em crianças com défice de atenção e hiperactividade. UTAD, Vila Real.

García, I., trans. Lima, J. (2001). Hiperactividade : prevenção, avaliação e tratamento na infância. Lisboa: McGraw-Hill.

Giacomini, M., \& Giacomini, O. (2006). Transtorno do Déficit de Atenção/hiperatividade e educação fisica. Retrieved 18/02/2012, from http://www.efdeportes.com/efd99/tdah.htm

Lopes, J. (2004). A Hiperactividade. Coimbra: Quarteto. 
PROBLEMS

OF EDUCATION

IN THE $21^{\text {st }}$ CENTURY

Volume 42, 2012

28 Mendes, C., \& Ribeiro, C. (2006). A Educação Física e o Transtorno de Déficit de Atenção com hiperatividade(TDA/H): um estudo para o profissional no espaço escolar. Retrieved 18/02/2012, from http://www.efdeportes.com/efd100/deficit.htm

Napole, N. (2008). TCC: TDAH na Escola: Conhecimento e Atuação do Professor de Educação Física. Retrieved 07-02-2012, from http://www.pedagogiaaopedaletra.com/posts/tcc-tdah-na-escolaconhecimento-e-atuacao-do-professor-de-educacao-fisica/

Parker, H. C., adapt. Soares, I. (2005). Desordem por défice de atenção e hiperactividade : um guia para pais, educadores e professores. Porto: Porto Editora.

Santos, D. (2007). A formação do professor de Educação Física para o trato com alunos portadores de transtorno de déficit de atenção e hiperatividade. Retrieved 18/02/2012, from http://www. efdeportes.com/efd114/transtorno-de-deficit-de-atencao-e-hiperatividade.htm

Sauvé, C., trans. Almeida, J. (2006). Domesticar a hiperactividade e o défice de atenção. Lisboa: Climepsi.

Sosin, D. (2006). Compreender a desordem por défice de atenção e hiperactividade. Porto: Porto Editora.

Advised by Rui Corredeira, University of Porto, Porto, Portugal

Received: January 25, 2012

Accepted: March 22, 2012

\begin{tabular}{|ll} 
Fábio Castro & MSc, Student, Faculty of Sport, University of Porto, Rua Dr. Plácido Costa, 91, \\
& $\begin{array}{l}\text { Porto, Portugal. } \\
\text { E-mail: fabio.leandro.castro@gmail.com } \\
\text { Website: http://www.fade.up.pt }\end{array}$ \\
\hline Paula Batista & $\begin{array}{l}\text { Ph.D, Associated Professor, Faculty of Sport, University of Porto, Porto, Portugal. } \\
\text { E-mail: pbatista@fade.up.pt } \\
\text { Website: http://www.fade.up.pt }\end{array}$ \\
\hline Susana Soares & $\begin{array}{l}\text { Ph.D, Associated Professor, Faculty of Sport, University of Porto, Porto, Portugal. } \\
\text { E-mail: susana@fade.up.pt } \\
\text { Website: http://www.fade.up.pt }\end{array}$
\end{tabular}

